Birgitte Norlyk*

\title{
Translation and Communication: The Influence of Culture and Context in Danish and British Sales Brochures
}

\begin{abstract}
Using a framework of culture and context, the present case study compares the English language version of a standardized sales brochure, produced in Denmark, to a culturally adapted brochure made especially for the British market. First, the analysis demonstrates the influence of cultural contexts on the concept of appropriate product settings. Second, the analysis illustrates how differences in coding and decoding processes influence the stylistics of product descriptions and the choice of selling points in Denmark and in Britain.
\end{abstract}

\section{Communication as transmission of data}

The identification of international communication barriers has been a subject of interest in a number of studies into culture, communication and marketing (de Mooij 1998: 26-32, 211-237, Usunier 1996: 383432). In Denmark, researchers have critically questioned the ethnocentric view that references to Danish cultural norms, Danish design and Danish know-how carry positive connotations in international communication (Gertsen 1990: 44-45, 50-56, Askegård et al. 1991: 111-120, Djursaa et al. 1991: 123-132). An ethnocentric approach to cross-cultural communication, as seen e.g. in the use of standardized sales material for all markets, may result in communication barriers even between markets which are normally regarded as fairly homogeneous.

The classic conduit model of communication views communication as a linear process in which data flow directly from sender to receiver. Basically, the process of communication is seen as a linear transmission

* Birgitte Norlyk

University of Southern Denmark

Engstien 1

DK-6000 Kolding 
of data in accordance with the mathematical telecommunication model introduced by tele-engineers Shannon and Weaver in the 1940s.

The view of communication as a linear activity focuses on the transmission process of communication. Miscommunication or misinterpretation of messages is explained as technical problems in transmission rather than cultural and contextual discrepancies surrounding the processes of coding and decoding. Operating strictly within a framework of transmission, the linear model pays little attention to sender and receiver and disregards the influence of cultural contexts on message coding and decoding. As the transmission model does not recognize differences in coding and decoding, the receiver is implicitly expected to interpret all transmitted data as intended by the sender.

For companies to successfully apply the linear model of communication in a non-technical context, e.g. in a marketing situation, presupposes the existence of cultural identity, national or professional, between sender and receiver (Winsor 1993: 183-185). Applied in nontechnical contexts, the linear model may result in ethnocentric approaches to communication as it fails to take into account the influence of culture on communication and interpretation. Its focus is directed at the process of transmission, while the influence of important factors such as culture, norms, and context remains underexposed. The interaction between sender and receiver and between culture and context is largely disregarded (Christensen 1994: 123).

The view of communication as a one-way linear process is reflected in the widespread use of standardized sales material and sales brochures. Justified by the logic of cost-cutting, standardized material is assumed to produce the same effect in all settings, irrespective of the possible existence of culturally determined preferences in individual markets.

\section{Communication and culture}

While the linear view of communication focuses on the process of transmission, more complex models of communication have been developed. Dealing specifically with the complex interaction between culture and communication, these models highlight the role of culture in the processes of coding and decoding. 
The culture perspective advocates a view of communication as constant processes of culturally determined coding and decoding of messages and symbols. Miscommunication or distortion of messages may occur in situations in which cultural discrepancies between sender and receiver prevent the message or symbol from being decoded correctly by the receiver.

Figure 1 (Dahl \& Habert in Søderberg \& Villemoes 1994: 49) illustrates the influence of culture and cultural filters on the coding and decoding processes that surround communication across cultures.

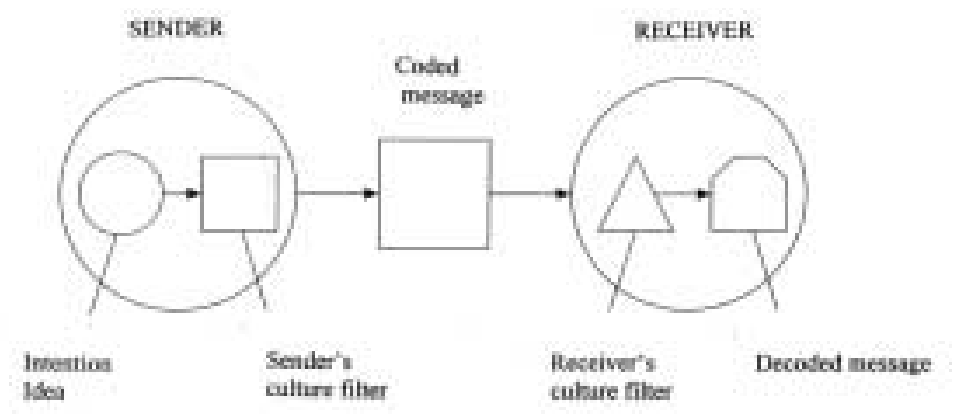

Figure 1: Cultural filters in cross-cultural communication

Research on semiotics and marketing (Buhl 1993: 165-173, Dahl \& Buhl 1993: 13-14, Larsen et al. 1991: 113, 117-122) further highlights a view of communication as ongoing processes of coding and decoding, stressing the importance of paying equal attention to the specific contexts surrounding both the sender and the receiver. To establish a framework for successful communication in a cross-cultural sales and marketing context, the semiotic approach highlights the importance of regarding the processes of coding and decoding as historically and culturally determined activities (Kragh 1997: 27-29).

\section{Communication and standardization}

Standardization of sales material presupposes the existence of cultural identity between sender and receiver in different markets. Following the linear approach to communication, standardized sales material presupposes that all symbols, photos or illustrations accompanying the 
sales text are decoded identically by all receivers irrespective of culturally determined preferences.

From a linguistic viewpoint, this presupposition of cultural identity is reflected in the belief that sales texts, generally, need not be modified or adapted to suit the receiving culture. The belief that translated versions of a source text have identical effects on all receivers fails to acknowledge the ethnocentric qualities of the source text. Semantic translations of a source text do not take into account that e.g. the choice of selling points and the preference for certain stylistic features over others might vary across markets (Horton 1998: 104-110). In standardized sales brochures, visual and textual elements are implicitly expected to transfer the sender's positive connotations to all receivers - irrespective of the individual culture in which the decoding and interpretation take place.

For businesses, it is important to recognize the influence of individual cultural contexts surrounding the processes of coding and decoding. Few messages, symbols, signs or texts have universal meanings. At the specific level of marketing communication, this means that standardized sales brochures and sales material may need to be critically revised as the decoding of colours, illustrations, product settings, language and style etc. may vary from one culture to the next.

The following analysis of sales brochures for the Danish and British markets offers examples of message distortion and communication barriers resulting from extensive standardization. As the case study demonstrates, Danish codes for design and aesthetics do not translate effortlessly. Even between fairly homogeneous markets such as Denmark and Britain differences exist as regards the marketing and presentation of products related to private homes. Culturally determined concepts of approved interior decorating and good taste do not translate easily.

\section{The case study}

The case study refers to a series of international sales brochures produced by Mors $\varnothing$ Jernst $\varnothing$ beri, since the 1850 s the major Danish producer of high-quality cast iron stoves for private homes. Firmly established in Denmark for many years, the company's marketing activities are now 
largely directed at the European markets as well as Japan, North America and South Africa.

Although it has now changed its marketing strategy, Mors $\varnothing$ Jernst $\varnothing$ beri formerly standardized its sales and marketing material for obvious costs reasons. Based on a concept of sales brochures originally produced for the Danish market, adaptations to export markets consisted in mere translations from the Danish source text into the appropriate language for each particular market. No further attempts were made to adapt the sales brochures to the individual markets. The lay-out of the brochure, the product descriptions and the photos showing the company's cast iron stoves set in Danish-style homes remained unchanged. While different national languages were recognized as a problem taken care of via translations, the processes of coding and decoding were implicitly assumed to take place in identical cultural contexts.

Based on reactions from its British subsidiary, however, the company in 1998 made a point of reconsidering the communication value of its standardized international sales brochures. While sales brochures for international markets traditionally were based on semantic translations of Danish selling points, feedback from subsidiaries suggested that cultural differences in individual markets needed to be taken into account to improve customer communication. Part of the feedback hinted that texts should be rewritten to suit individual national markets instead of being translated more or less verbatim from the Danish source text. As concerns the standardized presentation of products set in attractive private homes, feedback further suggested that the standardized brochures' photos of stoves set in Danish-style private homes might be counter-productive in other markets. The staging of what constitutes an attractive home - the very context and setting of the product needed to take into account that aesthetics related to the concept of attractive homes vary across cultures and markets (Djursaa \& Kragh 1998: 27-32).

Due to critical feedback from its British subsidiary concerning the communicative value of the standard version sales brochure, management at Mors $\varnothing$ Jernstøberi agreed to a communication experiment. Although the Danish standard brochure existed in an English language version, the British subsidiary was allowed to produce an alternative sales brochure targeted specifically at the British market. 


\section{Culture and context in product settings}

The difference between the standard brochure, made in Denmark, and the culturally adapted brochure, made in Britain, is striking. While both brochures aim at communicating the same message, language and style, product descriptions and product settings vary dramatically across cultures. Figures 2 and 3 illustrate the considerable degree of variation in aesthetics as concerns the concept of attractive homes in Danish and British cultural contexts.

The culturally adapted brochure, produced by the British subsidiary, presents the product in homes which British customers immediately identify as attractive British homes. The homes represented in the British brochure consistently repeat an aesthetical pattern traditionally favoured in British interior decorating. Different styles, different colours and different patterns in curtains, carpets and furniture dominate the British living rooms in which plenty of flowers, family photos, and a variety of objects d'art contribute to creating a sense of a British-style home, see figure 3.

Figure 2, the Danish concept of an attractive home, strikes a very different note in terms of aesthetics and interior decorating. Here, minimalism is the key word. In a Danish context, mixing colours, patterns and different styles is considered 'bad taste' and should be avoided. As opposed to the carpeted floors of the adapted British version, the Danish version favours natural materials. Bare wooden floor boards and tiles are considered attractive and hygienic as opposed to dusty carpets.

The product settings of the standard brochure, present different types of stoves surrounded by a range of other Danish quality products. These Danish quality products are easily decoded by Danish consumers who recognize Bang and Olufsen products, Danish designer furniture and designer lamps etc. In a Danish context, the constellation of different Danish quality products poses no difficulties in the decoding of the message as coding and decoding take place in identical cultural contexts. The presentation of the stove surrounded by other quality products firmly places the stove in a chain of established quality products (Buhl 1993: 166). Provided that coding and decoding take place in identical cultural contexts, visual representations of this kind may result in the receiver establishing a link between product values and personal values thus adding an extra dimension to the value of the product (Jantzen 1993: 58-61). 
Figure 2: A Danish-style home, standard brochure

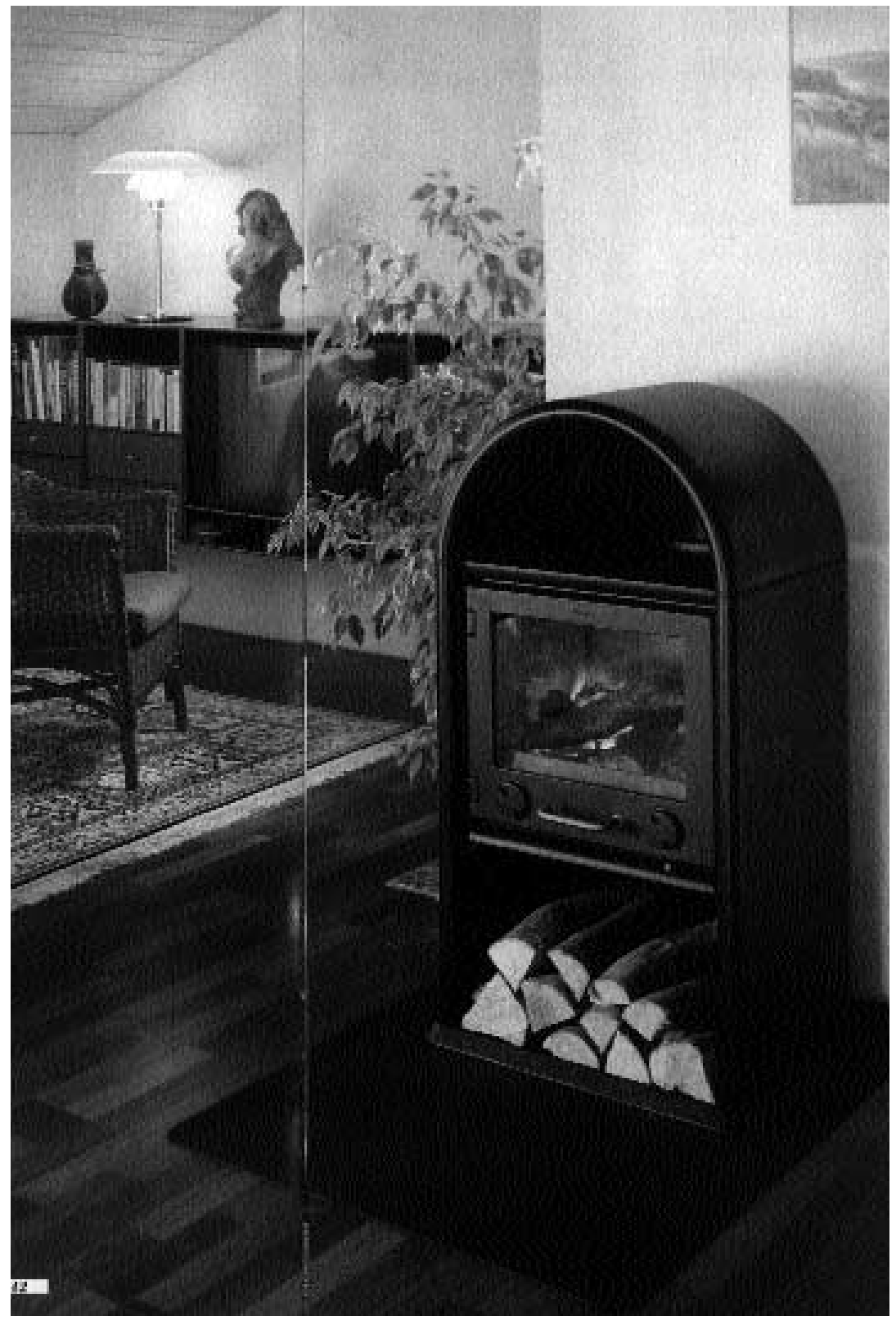


Figure 3: A British-style home, culturally adapted brochure

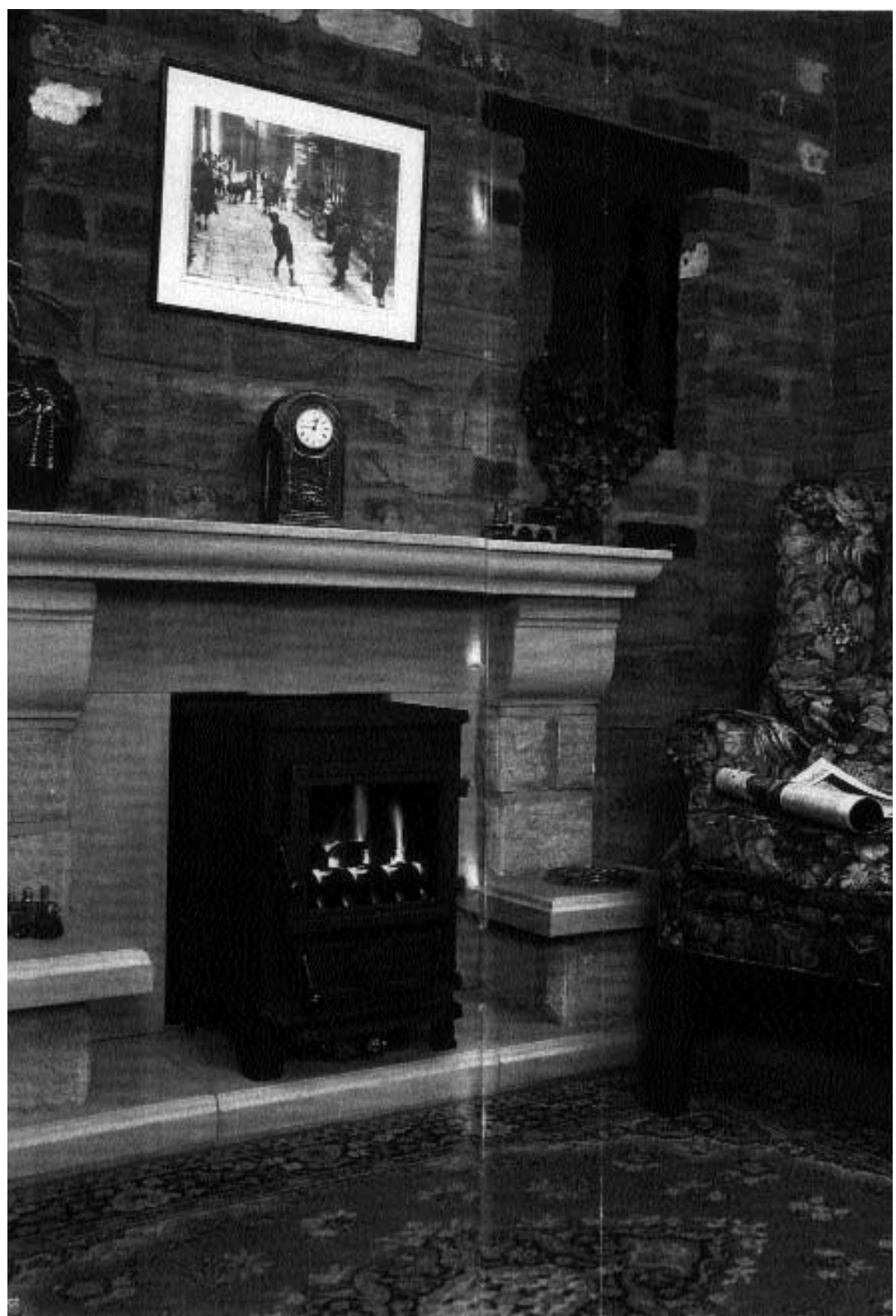


The Danish version of an attractive living room is carried through in all standardized versions of the company's sales brochures for exports markets. While the need for translations of texts was never questioned, the concept of attractive homes was ethnocentrically assumed to be culture-free. From a communication point of view, the ethnocentric quality of the product presentation in the Danish standard brochure makes it difficult for non-Danish receivers to decode correctly the company's message that quality homes deserve quality stoves. Attractive living rooms do not translate across cultures as the concept of home '- the central consumption context - carries the central message of the inhabitant's identity and culture, and poses the strongest cultural barriers against other forms of expression' (Djursaa \& Kragh 1998: 28). The appropriate setting for cast iron stoves reveals itself as strongly culture bound. Pictures and representations that work in one setting might offend or backfire in other settings - sometimes even within the same culture (Kostelnick 1993: 243-244).

Throughout, the culturally adapted British brochure places the stove in the fireplace. The stove is reinterpreted as a modern-day version of the fireplace, historically the focal point in English homes. In marked contrast, the Danish-made standard brochure consistently places the stove in a position that allows the heat to circulate freely in the room. From the Danish producer's point of view, placing the stove in the fireplace is wrong as this position prevents the stove from proving its excellent heating capacity.

The Danish producer wishes to communicate the design, the technology and the economic advantages of his product since these selling points traditionally work well in a Danish context. However, these selling points seem to lose part of their strength in a British context. Here, the concept of a cosy fireplace takes precedence over an efficient hightech stove and its advanced combustion air system. The appeal of the product lies in the mental representations and potential contexts it activates in the mind of the beholder. Products, as argued by de Mooij (1998: 4 ), 'are not culture-free, nor are the motivations of the people who buy them'. To motivate potential buyers, the communication processes surrounding the coding and decoding of product settings need to consider the cultural differences between markets. 


\section{The cultural context of language and style}

As illustrated in figures 2 and 3, successful communication in marketing need to consider the influence of cultural preferences in product representations and product settings. A standardized sales brochure presenting the product in a Danish context, surrounded by Danish symbols of approved good taste, might backfire when transferred to a culture in which aesthetics are founded on different traditions. As exemplified in the strongly felt need of the British subsidiary to produce their own sales brochure to sell Mors $\emptyset$ stoves in Britain, coding and decoding systems vary across cultures. Within the area of aesthetics in interior decorating Danish and British coding and decoding systems seem almost incompatible.

A comparison of language and style points in the same direction. The semantic translation into English of the standard brochure's Danish source text has undergone a complete rewrite in the culturally adapted brochure produced by the British subsidiary.

The semantic translation of the standard brochure ethnocentrically transferred the tone of voice and the selling points that worked in a Danish context. The appeal value of this text was considered low by the British subsidiary who redrafted the text in the version targeted at the British market.

The standardized brochure, based on a translation of the Danish text, is dominated by a neutral, nominal style containing factual references to product materials, product construction and product efficiency. The style is low key for a sales text. The text borders on a tendency towards understatement as in the low-key description of the convected stove heat - a prime selling point - as 'even and comfortable'.

In a Danish context, the controlled, technical description of the product may lend the seller a high degree of credibility. Judging from the rewrite made by the British subsidiary, this is not the case in a British context. Text examples 1 and 2 illustrate the stylistic differences between the low-key translated version of the Danish original as opposed to the version preferred by the British text writer. Both excerpts centre on the description of the stove heat - a vital selling point for cast iron stoves in both markets.

Example 1: Standardized text version, produced in Denmark 
'Solid cast iron has a unique ability to store heat and release it into the surroundings long after the fire has gone out.' ... 'The heavy dimensions and special alloy of cast iron store the heat and give even, comfortable heat release..'

\section{Example 2: Text produced in Britain}

'The appeal of cast iron lies not only in its ability to absorb the heat of the fire - wafting it slowly into the room long after the fuel is spent - but also in the ease with which it can be shaped. No other material can be moulded into such a variety of finishes - from softly rounded edges to crispy detailed ornamentation'... 'Cast iron stoves give the most luxurious warmth. The radiated heat from the body of the stove gently warms whilst the convected heat searches into every corner of the room.'

Example 1 offers the semantic translation of a selling point that works in a Danish context. The semantic translation assumes e.g. that the term 'heavy' carries identical, positive connotations in both cultural contexts. Stylistically, the selling point does not come across as a direct message from the seller. The subdued tone of voice and the emphasis on factual information resemble the neutral, informative text function in which the relationship between sender and receiver is not the issue. Facts and common sense are implicitly assumed to carry high persuasive value in this cultural context.

Example 2 illustrates the subsequent reinterpretation and adaptation of example 1 to suit a different cultural context in which persuasion and credibility make other demands on language and style (Horton 1998: 112, Norlyk 1996: 14-19). In the British-made version, heat and fire are personified and active. Stove heat is described as 'luxurious' rather than 'even and comfortable'. Stove heat 'gently warms' whilst it 'searches into every corner of the room' as opposed to the somewhat prosaic statement in the translation from the Danish source text 'Solid cast iron has a unique ability to store heat and release it into the surroundings long after the fire has gone out.'

Further, the use of the semi-poetic 'whilst' rather than plain 'while' accentuates the persuasive quality of this message. While factual information and rationality carried persuasive value in the Danish context of example 1, the adapted British version, example 2, highlights the sensuous appeal of heat and fire. Persuasion, in example 2, takes place via a carefully staged series of mental images that do not directly involve the technology and construction of the product. Example 2, the culturally 
adapted rewrite of example 1, mirrors the characteristics of the expressive, referential text function and pays less attention to the informative, descriptive character of the original Danish text.

The culture-bound differences in language and style provide important information in terms of successful communication. Since the producer of Mors $\emptyset$ stoves has experienced that sales texts containing a high degree of factual information work well in a Danish context, the producer naturally assumes that other markets should be addressed in the same way. From the Danish producer's point of view, the texts produced by the British text writer contain little relevant information. In a Danish context, certain excerpts of the British brochure may even come across as bordering on the comical, see example 4 .

The technical focus of the standardized brochure is illustrated in example 3. The description concerns recent developments in a new line of product designs. Again, sales communication is interpreted as information about product materials and product construction since this type of information is preferred in a Danish cultural context.

Example 3: Standardized brochure, made in Denmark.

..Solid cast iron has always been the best material for stoves. Cast iron is a unique material as it retains its shape during use. Doors and joints therefore always remain tight, and the environmentally-friendly combustion can be controlled completely.'

Product description in the culturally adapted British-made version centres on very different aspects as illustrated in example 4. Although examples 3 and 4 do not deal with the same version of a specific product, the difference in focus is clear. Again, the matter-of-fact Danish presentation contrasts vividly with the British description which centres on the looks and appearance of the product rather than its functional and technical capacities, see example 4.

Example 4: Text produced in Britain

... 'with rounded features and details, the Cleanheat Panther has perhaps the 'softest' appereance you might find in a stove. Created for the British market by the distinguished London design house of Queensberry Hunt, the shape is both gentle and solid.'

In a practical, business context the differences in language and style across markets and cultures are difficult to pinpoint beforehand. As pointed out by Frandsen et al. (1997: 36 - 40) traditional communica- 
tion models offer little assistance concerning the visual and linguistic aspects of market communication. Referring to Kotler (Kotler 1967: 501-504), Frandsen et al. (1997: 40) point out that although Kotler highlights the importance of staging the message emotionally, rationally or morally, he pays little attention to the linguistic and stylistic requirements needed in different cultural contexts.

\section{Communication and product names}

The tendency of the Danish producer to focus on the technical and functional aspects of the product is likewise reflected in the choice of product names. From a communication perspective, the choice of product names is an important one. The initial suggestion of the meaning and identity of a product lies in its name (Stigel 1993: 34) which sets the frame for connotations and decoding processes at the receiving end.

Product names, in the Danish source text, take the form of product numbers in combination with acronyms. Organizations characterized by technical cultures often prefer the use of acronyms and numbers when naming their products as the combination of numbers and acronyms suggests know-how and state-of-the-art technology in technical contexts (Giles \& Coupland 1991: 23, Norlyk 1997: 63).

The semantic translations of the Danish source text in the standard brochures keep the names chosen by the Danish producer whose technical focus is reflected in the choice of names. Product names such as the 1400 series containing product variations such as stove 1410, stove 1415 and stove 1420 BUO etc. may hold positive connotations in cultural contexts favouring technical values. The present case study has no empirical evidence of how international customers react to product names such as the 1420 BUO or the Soapstone 5043. However, from a communication perspective, it seems fair to assume that a number of potential customers may find it difficult to remember these names and to distinguish between different product variations. Apart from the possible high-tech connotations of these product names, the bare combination of numbers and acronyms holds only limited associative value for the receiver.

Once again, the culturally adapted British brochure shows a different approach to communication. The original product names of the standard brochure have undergone a cultural transformation in which the 
technical focus of the original names has been toned down. Product names, in the adapted British version, connote a different set of images. No longer referred to as the 1410, the 1415 etc., products and product names in the British version associate Nature and living beings. Names such as the Squirrel, the Panther, the Lion, the Swan etc. have replaced the numbers and acronyms of the standard version.

The move away from the technical focus of the Danish source text towards a more intimate tone of voice is clearly reflected in the choice of product names in the British version. The preference for an intimate, even personified product description is further illustrated in the descriptions of products within the same series. While the standardized text operates with product 'series', e.g. the 1400 series, the 5000 series etc., the culturally adapted British version operates with product 'families' connoting a personal relationship. Products within the same series are described in terms of family members as illustrated in example 5.

Example 5: Product relations in family terms, British text.

'The Cleanheat Squirrel is now a firmly established addition to the morsø family. It is based on its highly successful brother, the Squirrel.... Like its brother the Squirrel, the advanced Cleanheat Squirrel has a generous firebox size, an enclosed riddling system...etc.'

Culturally adapted sales brochures enable the sender to target special selling points that might otherwise never appear in a standard text for all markets. While the standard version refers to the metric system in its list of product measurements, the British version goes one step further. Although the British brochure refers to the metric system, it recognizes the importance of relating centimetres to inches when addressing British customers, see example 6.

Example 6: Relating the metric system to a context of inches. British text.

'The Squirrel ... was designed over a decade ago with the dimensions of the standard 22" British fireplace in mind.'

While this information is highly relevant in a British context, it would never appear in a translated version based on a Danish source text as references to inches are not relevant in a Danish context. 


\section{Conclusions}

This paper argues for the need to consider the influence of national cultures in international marketing communication. Comparing a standardized version of a sales brochure with a culturally adapted version, the paper demonstrates the communication barriers surrounding the aesthetics of product presentation. As concerns the subtle communication barriers related to culturally determined preferences in language and style, the paper offers examples of cross-cultural differences in the persuasive strategy of sales texts. Contrasting an international standard version of a sales brochure with a targeted version made especially for the British market, the paper argues that selling points that work well in one context do not always translate effortlessly into other cultural contexts.

From the point of view of business economics, the concept of standardization is an attractive one. For the producer, standardization is cost-saving and secures a high degree of image control in international markets as the influence of subsidiaries and agents on product presentation is limited.

From a communication point of view, however, the unrecognized, ethnocentric influence of the sender's cultural context may pose a problem in terms of the communicative quality of standardized sales messages and product presentations. As demonstrated in the case study, cultural differences influence the way in which products are perceived and presented. Successful communication must recognize the existence of culturally-determined differences - even between such fairly homogeneous markets as Denmark and Britain.

\section{References:}

Askegård, Søren, Gertsen, Martine Cardel og Madsen, Tage Koed (1991). Danske kulturbarrierers betydning for virksomhederne. In Ledelse og Erhvervsøkonomi 3/91. Foreningen af danske civiløkonomer. 111-123.

Blyler, N.R. \& Thralls, C (eds.), (1993). Professional Communication: The social perspective. Sage.

Buhl, Claus (1993). Produktsemiotik. In Ledelse og Erhvervs $\phi$ konomi 3/93. Foreningen af danske civiløkonomer. 165-173.

Christensen, Lars Thøger (1994). Markedskommunikation som organisationsmåde: en kulturteoretisk analyse. Akademisk forlag.

Dahl, Henrik og Buhl, Claus (1993). Marketing og semiotik. Akademisk forlag. 
Djursaa, Malene, Kragh, Simon og Møller, Jan Holm (1991). Det nationale image i eksportmarkedsføringen. In Ledelse og Erhvervs $\phi$ konomi, 3/91. Foreningen af danske civiløkonomer. 123-132.

Djursaa, Malene \& Kragh, Simon Ulrik (1998). Central and peripheral consumption contexts: the uneven globalisation of consumer behaviour. In International Business Review, Pergamon Press. 23-38.

Frandsen Finn, Johansen, Winni \& Nielsen, Anne Ellerup (1997). International markedskommunikation i en postmoderne verden, Systime.

Gertsen, Martine Cardel (1990). Fjernt fra Danmark - Interkulturel kompetence i teori og praksis. Handelshøjskolens forlag, Busck.

Giles, H. \& Coupland, N. (1991): LANGUAGE: CONTEXTS and CONSEQUENCES. Open University Press.

Horton, David (1998). Translation assessment: Notes on the interlingual transfer of an advertising Text. In International Review of Applied Linguistics in Learning Texts. Vol. xxxvi. Heidelberg. Gross Verlag. 95-119.

Jantzen, Christian (1993). Mœrk varen. In Jensen, Jens F, Rasmussen, Tove Arendt \& Stigel, Jørgen (eds.) (1993). Reklame - Kultur, Ålborg Universitetsforlag. 55-84.

Kostelnick, Charles (1993). Viewing functional pictures in context. In Blyler, N.R. \& Thralls, C. (eds.) (1993). Professional Communication: The Social Perspective. Sage. 243-256.

Kotler, Philip, (1967). Marketing management. German edition (1980). Poeschel Verlag.

Kragh, Simon Ulrik (1997). Er en spade en spade? Semiotisk markedsføring og kommunikationsanalyse. In Hjort, Katrin (ed.) (1997). Diskurs: Analyser af tekst og kontekst. Samfundslitteratur. 23-42.

Larsen, Hanne Hartvig, Mick, David Glen \& Alsted, Christian (eds.) (1991). Marketing and semiotics, Handelshøjskolens forlag.

Mooij, Marieke de (1998). Global marketing and advertising: Understanding cultural paradoxes. Sage.

Norlyk, Birgitte (1996). Miscommunication and discourse practices in occupational cultures. In Journal of Applied Linguistics, Vol. 6, No.1. 7-20.

Norlyk, Birgitte (1997). Virksomhedskommunikation: Ingeniørsprog og marketingsprog i højteknologiske virksomheder. Skriftserie 17.98, Institut for erhvervssprog, Handelshøjskole Syd.

Stigel, Jørgen (1993). Det vigtigste er som regel det, der ikke er. In Jensen, Jens F, Rasmussen, Tove Arendt \& Stigel, Jørgen (eds.). Reklame - Kultur. Ålborg universitetsforlag. 17-54.

Søderberg, Anne-Marie og Villemoes, Annette (1994). Undervejs. Samfundslitteratur.

Usunier, Jean-Claude (1996). Marketing across cultures. Prentice Hall.

Winsor, Dorothy (1993). Owning Corporate Texts. Journal of Business and Technical Communication. Vol. 7, Sage. 179- 195. 